\title{
Penerapan Model Gravitasi Data Panel: Kajian Perdagangan Internasional Indonesia ke Negara Anggota ASEAN
}

\author{
(Application of Gravity Model Panel Data: International Trade Study of Indonesia to ASEAN \\ Members)
}

\author{
Yuni Mas Rony Ambarita1, ${ }^{1}$ Timbang Sirait ${ }^{2}$ \\ Politeknik Statistika STIS ${ }^{1}$ \\ Politeknik Statistika STIS ${ }^{2}$ \\ Jalan Otista Raya Gang Mangga No.15 \\ E-mail: 15.8954@stis.ac.id
}

\begin{abstract}
ABSTRAK
Penelitian ini bertujuan untuk mengkaji ulang perdagangan internasional antara Indonesia dengan 9 negara anggota ASEAN menggunakan model gravitasi. Perdagangan internasional Indonesia dengan 9 negara anggota ASEAN ini diestimasi dengan teknik data panel. Estimasi yang dilakukan adalah untuk model ekspor dan impor. Data cross section yang digunakan adalah data 9 negara anggota ASEAN. Periode observasi yang digunakan adalah dari tahun 2010 hingga 2017. Hasil estimasinya menyatakan bahwa pada model ekspor variabel PDB negara anggota ASEAN dan rasio industri terhadap PDB signifikan berpengaruh secara positif terhadap ekspor Indonesia ke negara anggota ASEAN, sedangkan indeks kesamaan berpengaruh secara negatif terhadap ekspor Indonesia ke negara anggota ASEAN. Adapun variabel jarak tidak signifikan berpengaruh terhadap ekspor Indonesia ke negara anggota ASEAN namun memiliki koefisien yang negatif. Pada model impor, variabel PDB Indonesia, indeks kesamaan, dan rasio industri terhadap PDB secara signifikan berpengaruh positif terhadap impor Indonesia dari negara anggota ASEAN, sebalikmya variabel yang signifikan secara negatif berpengaruh terhadap impor Indonesia dari negara anggota ASEAN adalah jarak dan dummy MEA. Negara anggota ASEAN yang masih memiliki potensi besar untuk menjadi pasar ekspor Indonesia adalah Laos, Malaysia, Thailand, dan Brunei Darussalam.
\end{abstract}

Kata kunci: model gravitasi, ekspor, impor, data panel, ASEAN

\section{ABSTRACT}

This study aims to examine the trade of Indonesia with 9 ASEAN members using the graviy model. Indonesia's trade with 9 ASEAN members using the panel data estimastion technique. Estimation of the gravity model for export and import are carried on. Data comprise 9 members of ASEAN as cross section data. The observation comprise the period 2010-2017. The estimation results state that in the export model the variable GDP of ASEAN member countries and the industry to GDP ratio significantly affect Indonesian exports to ASEAN member countries, while the similarity index negatively affects Indonesian exports to ASEAN member countries. The distance variable does not significantly affect Indonesian exports to ASEAN member countries but has a negative coefficient. In the import model, Indonesian GDP, the similarity index, and the industry to GDP ratio significantly have a positive effect on Indonesian imports from ASEAN member countries, the variables that are significantly negative affecting Indonesian imports from ASEAN member countries, in the other hand variables that are significantly have negative impact on Indonesian imports from ASEAN member countries are distance and dummy MEA. ASEAN member countries that still have great potential to become Indonesia's export markets are Laos, Malaysia, Thailand and Brunei Darussalam.

Keywords: gravity model, export, import, panel data, ASEAN 
Penerapan Model Gravitasi Data Panel: Kajian Perdagangan Internasional Indonesia ke Negara Anggota ASEAN...(Ambrita dan Sirati) 


\section{PENDAHULUAN}

Integrasi ekonomi memiliki prinsip dan mekanisme yang sama dengan perdagangan bebas. Secara teoritis, integrasi ekonomi mengacu pada suatu kebijakan komersial atau kebijakan perdagangan yang secara sengaja menurunkan atau menghapuskan hambatan-hambatan dalam perdagangan diantara negara-negara anggota yang sepakat untuk membentuk suatu integrasi ekonomi. Semua bentuk hambatan dalam perdagangan baik hambatan tarif maupun non tarif secara sengaja diturunkan atau bahkan dihapuskan diantara negara anggota. Namun, bagi negara yang bukan anggota, maka pemberlakuan hambatan berupa tarif dan non tarif tergantung dari kebijakan negara masing-masing. Dalam integrasi ekonomi terjadi perlakuan diskriminatif antara negara-negara anggota dengan negara-negara bukan anggota dalam melakukan perdagangan, sehingga dapat memberikan dampak kreasi dan dampak diversi bagi negara-negara anggota (Salvatore, 1997). Krugman (1991) memperkenalkan suatu angapan bahwa secara alami blok perdagangan didasarkan pada pendekatan geografis yang dapat memberikan efisiensi dan meningkatkan kesejahteraan bagi anggotanya.

Tujuan yang paling mendasar dari integrasi ekonomi ini adalah untuk meningkatkan volume perdagangan barang dan jasa antar negara, meningkatkan perpindahan modal dan tenaga kerja, meningkatkan produksi, meningkatkan efisiensi produksi serta meningkatkan daya saing produk yang dihasilkan oleh negara anggota. Pembentukan integrasi ekonomi pada akhirnya akan menciptakan dampak meningkatnya kesejahteraan negara-negara anggota secara keseluruhan karena akan mengarah pada peningkatan spesialisasi produksi suatu negara, yang didasarkan pada keuntungan komparatif (Lapipi, 2005). Tujuan yang telah dijabarkan sebelumnya sesuai dengan tujuan Sustainable Development Goals (SDGs) atau yang biasa disebut Pembangunan Berkelanjutan, tepatnya poin yang ke tiga dan tujuh belas yaitu kehidupan sehat dan sejahtera dan kemitraan untuk tujuan.

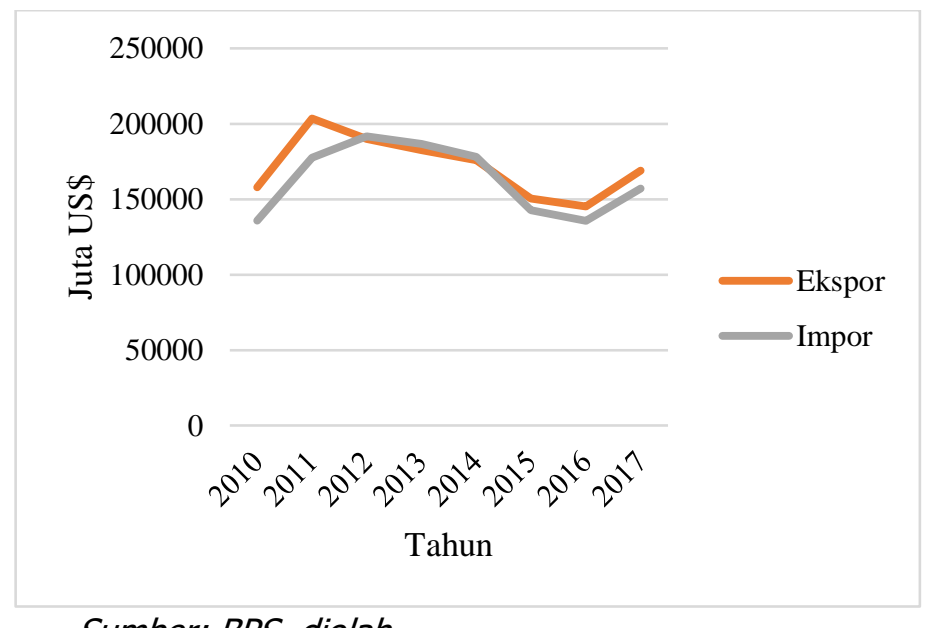

Sumber: BPS, diolah.

Gambar 1. Ekspor dan impor Indonesa tahun 2010-2017.

Berdasarkan Gambar 1, terlihat bahwa ekspor dan impor Indonesia mengalami fluktuasi selama 2010-2017. Sejak tahun 2013 ekspor dan impor Indonesia terus mengalami penurunan hingga tahun 2016. Walaupun begitu, sejak tahun 2015 hingga 2017 ekspor Indonesia lebih besar dibandingkan impor sehingga Indonesia mengalami net ekspor atau surplus neraca perdagangan. Pada tahun 2015 nilai ekpor Indonesia sebesar 150.366,3 juta US\$, sedangkan pada tahun 2016 nilai ekspor Indonesia sebesar 145.186,2 juta US\$. Dapat dilihat bahwa nilai ekspor Indonesia mengalami penurunan dari tahun 2015 ke tahun 2016. Namun pada tahun 2017 nilai ekspor Indonesia meningkat menjadi $168.828,2$ juta US\$, meningkat 16,28 persen dibanding tahun 2016 . Jika melihat nilai impor Indonesia dari tahun 2015 ke tahun 2016 mengalami penurunan yaitu dari 142.694,8 juta US\$ menjadi 135.652,8 juta US\$. Sedangkan di tahun 2017 impor Indonesia mengalami kenaikan menjadi 156.985,5 juta US\$, meningkat 15,72 persen dibanding tahun 2016. 
Indonesia sendiri berada di kawasan Asia Tenggara dimana kawasan ini membentuk suatu kerjasama regional yang disebut ASEAN. Negara anggota ASEAN telah membentuk berbagai bentuk kerjasama dalam berbagai bidang. Salah satunya kerjasama yang telah dibentuk oleh negara anggota ASEAN adalah ASEAN Free Trade Area (AFTA) pada tahun 1992 yang bertujuan untuk menghilangkan batasan tarif diantara negara anggota ASEAN. Selanjutnya pada tahun 2009 disahkan pula ASEAN Trade in Goods Agreement (ATIGA) untuk memfalisitasi perdagangan yang lebih lancar dan mempersiapkan negara anggota ASEAN untuk memasuki Masyarakat Ekonomi ASEAN (MEA) di tahun 2015. Menurut Widyasanti (2010) ASEAN adalah pasar ekspor utama Indonesia.

Kawawan ASEAN memiliki arti penting terhadap perekonomian dunia karena dianggap memiliki potensi pertumbuhan yang tinggi. Hal ini disebabkan oleh beberapa hal seperti pertumbuhan ekonomi yang relatif cepat daripada pertumbuhan ekonomi dunia, dan juga populasi ASEAN yang cukup tinggi sekitar 650 juta jiwa. Sehingga Indonesia memiliki potensi perdagangan yang sangat besar terhadap negara anggota ASEAN.

Indonesia memiliki kontribusi PDB terbesar diantara negara anggota ASEAN lainnya dengan total share lebih dari 38 persen sejak tahun 2010 hingga tahun 2017, yang selanjutnya diikuti oleh Thailand di peringkat kedua dengan total share sebesar 15 persen, Malaysia di peringkat ketiga sebesar 13 persen, dan Singapura di peringkat keempat sebesar 11 persen.

Walaupun PDB Indonesia adalah yang terbesar diantara negara anggota ASEAN lainnya akan tetapi ekspor dan impor Indonesia bukanlah yang terbesar di ASEAN. Berdasarkan data ASEAN Secretariat Impor ASEAN pada tahun 2010 didominasi oleh negara Singapura, Indonesia, Malaysia, dan Thailand dan begitu pula pada tahun 2017. Singapura tetap berada di peringkat pertama dengan share sebesar 25,39 persen pada tahun 2017, diperingkat kedua terdapat Malaysia dengan share sebesar 17,89 persen, diikuti oleh Thailand dan Indonesia dengan masing-masing share sebesar 16,02 dan 14,08 persen pada tahun 2017. Hal yang menarik dalam perkembangan share impor negara anggota ASEAN di ASEAN adalah bahwa share Singapura, Malaysia, dan Indonesia mengalami penuruan di tahun 2017 jika dibandingkan dengan tahun 2010, sedangkan share impor Thailand mengalami kenaikan sebesar 2,33 persen dari 13,69 persen menjadi 16,02 persen.

Hal yang sama juga terjadi terhadap share ekspor negara anggota ASEAN di ASEAN, dimana Singapura, Malaysia, Thailand, dan Indonesia masih mendominasi ekspor di ASEAN. Pada tahun 2010 ekspor Indonesia tercatat sebesar 12,61 persen dan pada tahun 2017 mengalami kenaikan sebesar 0,04 persen menjadi 12,65 persen, angka yang sangat kecil dibandingkan kenaikan share ekspor yang dialami oleh Malaysia dan Thailand. Pada tahun 2017 Indonesia tetap berada di peringkat ke empat dibawah Singapura, Malaysia, dan Thailand.

Ekspor dan impor Indonesia dengan negara ASEAN cukup fluktuatif dari tahun 2010 hingga 2017. Terlihat bahwa pada tahun 2011 ekspor maupun impor Indonesia dengan negara-negara ASEAN mengalami peningkatan. Jika ditelaah lagi impor Indonesia mengalami pertumbuhan di tiap tahunnya sebesar 2,27 persen, sedangkan ekspor Indonesia ke negara anggota ASEAN rata-rata tiap tahunnya mengalami penurunan sebesar 2,03 persen. Hal ini didukung oleh data dari tahun 2010 hingga 2017 neraca perdagangan Indonesia dengan negara anggota ASEAN selalu defisit, sangat ironis dibandingkan dengan kondisi neraca perdagangan Indonesia yang sejak tahun 2010 hingga 2017 dimana masih terdapat lima tahun Indonesia mengalami surplus neraca perdagangan atau net ekspor. 


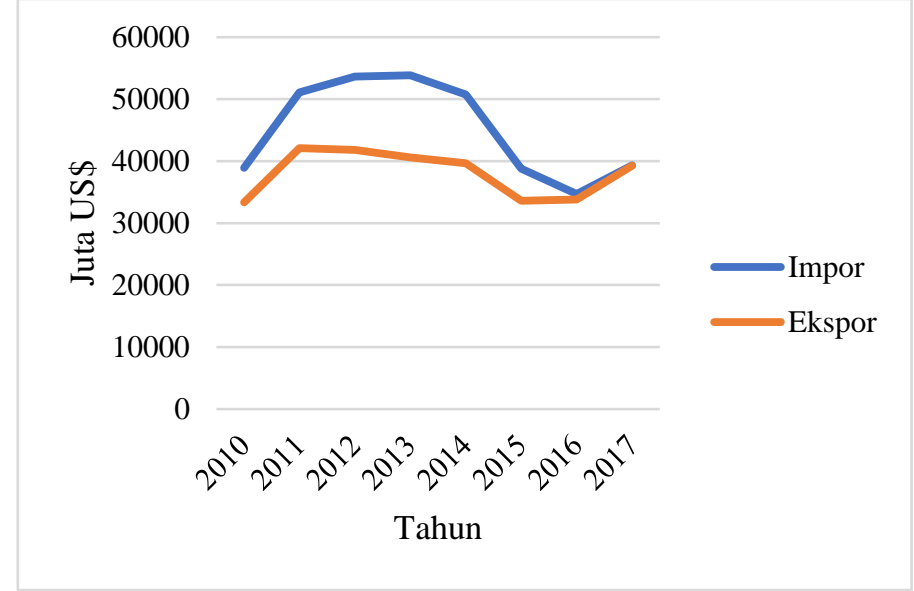

Sumber: BPS, diolah.

Gambar 2. Ekspor dan impor Indonesia dengan negara anggota ASEAN tahun 2010-2017.

Adanya ketidaksesuaian dengan tujuan awal integrasi negara anggota ASEAN dan harapan pemerintah terhadap kerjasama dengan negara anggota ASEAN dalam perdagangan internasional (ekspor dan impor) Indonesia serta belum optimalnya pemanfaatan perjanjian perdagangan Indonesia dengan negara anggota ASEAN kemudian menarik untuk diteliti.

Untuk dapat mengoptimalkan perjanjian perdagangan yang telah terwujud antar negara-negara ASEAN, perlu untuk dilakukan analisis perdagangan internasional Indonesia dengan negara anggota ASEAN. Oleh sebab itu, penelitian ini bertujuan untuk 1) menggambarkan perdagangan internasional (ekspor dan impor) Indonesia ke negara anggota ASEAN tahun 2010-2017, 2) mengkaji faktor-faktor yang mempengaruhi perdagangan internasional (ekpor dan impor) Indonesia dengan negara anggota ASEAN tahun 2010-2017, dan 3) melihat potensi perdagangan internasional (ekspor dan impor) Indonesia dengan negara anggota ASEAN.

\section{METODE}

\section{Landasan Teori}

Model gravitasi adalah salah satu model kerangka empiris yang sering digunakan untuk menganalisa perdagangan bilateral, efek liberalisasi dan perjanjian-perjanjian perdagangan. Timbergen pada tahun 1962 menganalisis arus perdagangan bilateral antar negara-negara Eropa. Bentuk sederhana dari model gravitasi Timbergen bahwa besarnya arus perdagangan antara dua negara dapat dijelaskan oleh ukuran ekonomi dan jarak geografis, sehingga formulasi rumusnya dapat ditulis sebagai berikut:

$$
F_{i j}=A \frac{Y_{i} Y_{j}}{D_{i j}}
$$

Dimana $F_{i j}$ merupakan arus perdagangan dari negara i ke negara $\mathrm{j}$ baik berupa nilai maupun volume perdagangan, $Y_{i}$ dan $Y_{j}$ merupakan ukuran ekonomi yang relevan dari negara $i$ dan negara $j$ yang biasanya direpresentasikan dalam besaran PDB, $D_{\mathrm{ij}}$ merupakan jarak geografis antara negara i dan negara j, lalu A merupakan konstanta.

Meski pada awalnya model gravitasi memiliki dasar teori yang kurang kuat, namun beberapa peneliti berusaha untuk membangun dan menyempurnakan teori model gravitasi ini. Batra (2004) merupakan salah satu peneliti yang menyempurnakan model gravitasi Timbergen. Adapun model gravitasi Batra adalah sebagai berikut:

\section{Keterangan:}

$$
L n T_{i j}=\beta_{0}+\beta_{1} L n Y_{i}+\beta_{2} L n Y_{j}+\beta_{3} L n D_{i j}+\sum_{s=1}^{N} \lambda_{s} G_{s}
$$

$\mathrm{T}_{\mathrm{ij}} \quad$ : arus perdagangan dari negara asal i ke negara tujuan $\mathrm{j}$

$\mathrm{Y}_{\mathrm{i}} \quad$ : ukuran ekonomi yang relevan dari negara $\mathrm{i}\left(\mathrm{PDB}_{\mathrm{i}}\right)$ 
$Y_{j} \quad$ : ukuran ekonomi yang relevan dari negara $\mathrm{j}$ (PDBj)

$D_{\mathrm{ij}} \quad$ : jarak antara negara i dan $\mathrm{j}$

$\mathrm{G}_{\mathrm{s}} \quad$ : faktor lainnya yang memengaruhi perdagangan antara negara $\mathrm{i}$ dan $\mathrm{j}$

Pada penerapan model gravitasi, koefisien yang diduga bertanda positif terhadap arus perdagangan yakni ukuran ekonomi (PDB) negara i dan negara j dan koefisien bertanda negatif adalah jarak. Jarak merupakan proksi yang digunakan untuk menggambarkan biaya transportasi. Asumsi yang digunakan adalah semakin tingginya tingkat pendapatan (PDB) akan berakibat pada semakin banyaknya ekspor yang dilakukan negara pengekspor. Sama halnya jika pendapatan tinggi di negara pengimpor akan berakibat semakin banyaknya impor yang dilakukan oleh negara tersebut. Di sisi lain semakin jauhnya jarak kedua negara mengindikasikan biaya transportasi yang semakin mahal sehingga arus perdagangan semakin kecil. Adapun variabel lain yang memengaruhi perdagangan seperti industrialisasi, indeks kesamaan perekonomian dan perjanjian perdagangan.

Beberapa faktor yang berpengaruh terhadap perdagangan luar negeri:

a. Pendapatan Domestik Bruto (PDB)

PDB negara eksportir mengukur kapasitas produksi suatu negara, sedangkan PDB negara importir mengukur kapasitas absorbsi negara tersebut. Sehingga kenaikan PDB diperkirakan dapat meningkatkan ekspor maupun impor suatu negara (Kalbasi, 2001).

b. Jarak

Jarak merupakan proksi untuk biaya transportasi (Krugman, 1991). Oleh karena itu, semakin jauh jarak antara negara eksportir dan importir akan menyebabkan biaya untuk melakukan impor maupun ekspor menjadi semakin mahal yang mendorong suatu negara untuk menurunkan impor dan ekspor.

c. Indeks Kesamaan

Teori dari Helpman dan Krugman (1985) menjelaskan kesamaan dalam ukuran perekonomian mempunyai pengaruh positif terhadap perdagangan, negara yang hampir sama ukuran perekonomiannya akan melakukan perdagangan yang lebih besar. Namun Yeshineh (2014) menyatakan bahwa kesamaan ukuran suatu negara akan berdampak negatif kepada perdagangan kedua negara, terutama bagi negara yang masih mengandalkan produk-produk pertanian atau rendah teknologi.

d. Rasio sektor industri dalam PDB

Besarnya proporsi sektor industri pada suatu negara mengindikasikan bahwa perekonomian negara tersebut maju dilihat dari sektor produksinya, sehingga dapat dikatakan bahwa sektor perdagangannya maju, termasuk sektor ekspornya.

e. Penjanjian perdagangan

Adanya perjanjian perdagangan dengan menghapus habatan tarif maupun non tarif dalam kegiatan perdagangan akan memicu suatu negara untuk meningkatkan perdagangan karena nilai barang yang lebih murah dan kemudahan dalam bertransaksi.

\section{Metode Pengumpulan Data}

Penelitian ini menggunakan data sekunder dari sembilan negara mitra dagang dengan periode waktu yang digunakan adalah dari tahun 2010 hingga tahun 2017. Berikut ini adalah rincian data yang digunakan:

1. Data nilai ekspor dan impor Indonesia dengan negara anggota ASEAN diperoleh dari Badan Pusat Statistik.

2. Data Produk Domestik Bruto Indonesia dan negara mitra dagang serta rasio sektor industri terhadap PDB diperoleh dari World Bank.

3. Data jarak ibukota Indonesia dengan ibukota negara mitra dagang dalam satuan km diperoleh dari https://www.distancecalculator.net/

4. Indeks Kesamaan (Similarity Index) dihitung berdasarkan perhitungan dengan rumus sebagai berikut:

$$
\text { Indeks Kesamaan }=1-\left(\frac{P D B_{\text {Indot }}}{P D B_{\text {Indo } t}+P D B_{J} t}\right)^{2}-\left(\frac{P D B_{J t}}{P D B_{\text {Indo } t}+P D B_{J} t}\right)^{2}
$$


Keterangan:

$\mathrm{PDB}_{\mathrm{jt}}$

: produk domestik bruto negara anggota ASEAN j pada tahun ke-t

$\mathrm{PDB}_{\text {indot }}$ : produk domestik bruto Indonesia pada tahun ke-t

\section{Metode Analisis}

Terdapat dua metode yang dilakukan dalam penelitian ini yaitu analisis dekriptif dan analisis inferensia. Analisis dekriptif dapat memberikan gambaran secara umum perkembangan ekspor dan impor Indonesia terhadap negara anggota ASEAN menggunakan grafik. Sementara itu, analisis inferensia dalam penelitian ini adalah analisis regresi data panel dengan model gravitasi.

Penelitian ini menggunakan variabel jarak geografis yang merupakan variabel time invariant (tidak bervariasi dalam waktu) menyebabkan ternyadinya singularitas pada matriks variabel bebas. sehingga tidak bisa menggunakan model efek tetap (Gujarati dan Poerter, 2008). Oleh sebab itu, untuk memilih model terbaik dalam penelitian ini dilakukan uji Breush-Pagan Lagrange Multiplier untuk memilih antara model efek umum atau efek acak yang lebih baik untuk mengestimasi model. Ketika ketika nilai BP-LM lebih besar dari nilai statistik chi-square dengan derajat bebas $1\left(\mathrm{X}^{2}{ }_{(1)}\right)$ atau p-value lebih kecil dari 0,05 dapat disimpulkan bahwa model efek acak lebih baik dibandingkan model efek umum.

Berikut adalah model yang digunakan pada penelitian ini:

Model ekspor:

LnEskpor $_{i j t}=\beta_{0}+\beta_{1}$ LnPDB $_{j \mathrm{jt}}+\beta_{2}$ LnJarak $_{\mathrm{ij}}+\beta_{3}$ LnIndeksKesamaan $_{\mathrm{ijt}}+\beta_{4}$ DummyMEA $\beta_{5}$ Industri $_{\mathrm{it}}$ $+\lambda_{\mathrm{i}}+\varepsilon_{\mathrm{it}}$

Model impor:

LnImpor $_{i j t}=\beta_{0}+\beta_{1}$ LnPDB $_{i t}+\beta_{2}$ LnJarak $_{i j}+\beta_{3}$ LnIndeksKesamaan $_{i j t}+\beta_{4}$ DummyMEA $+\beta_{5}$ Industri $_{j \mathrm{jt}}$ $+\gamma_{i}+\omega_{i t}$

Keterangan:

i

j

$\mathrm{t}$

LnEskpor $_{i j t}$

LnImpor $_{i j t}$

$\operatorname{LnPDB}_{j \mathrm{t}}$

$\operatorname{LnPDB}_{\text {it }}$

LnJarak

LnIndeksKesamaan $_{i j t}$

Industrit

Industri $_{j t}$

DummyMEA

$\lambda_{i}$ dan $\gamma_{i}$

$\varepsilon_{\text {it }}$ dan $\omega_{\text {it }}$
: negara Indonesia

$: 1,2, \ldots, 9$ (negara anggota ASEAN)

$: 1,2, \ldots, 8$ (periode waktu penelitian 2010-2017)

: logaritma natural nilai total ekspor Indonesia ke negara j pada periode tahun ke-t

: logaritma natural nilai total impor Indonesia ke negara j pada periode tahun ke-t

: logaritma natural produk domestik bruto negara anggota ASEAN j pada tahun ke-t

: logaritma natural produk domestik bruto Indonesia pada tahun ke-t

: logaritma natural jarak geografis antara negara Indonesia dengan negara anggota ASEAN $\mathrm{j}$ pada tahun ke-t

: logaritma natural indeks kesamaan antara negara Indonesia dengan negara anggota ASEAN j pada tahun ke-t

: rasio sektor industri terhadap PDB negara Indonesia pada tahun ke-t

: rasio sektor industri terhadap PDB negara anggota ASEAN pada tahun ke$\mathrm{t}$

: variabel dummy untuk tahun sebelum dan setelah realisasi MEA ( $1=$ setelah diberlakukan MEA; $0=$ sebelum diberlakukan MEA)

: galat individu

: galat komposit 


\section{HASIL DAN PEMBAHASAN}

\section{Gambaran Umum Ekspor Indonesia}

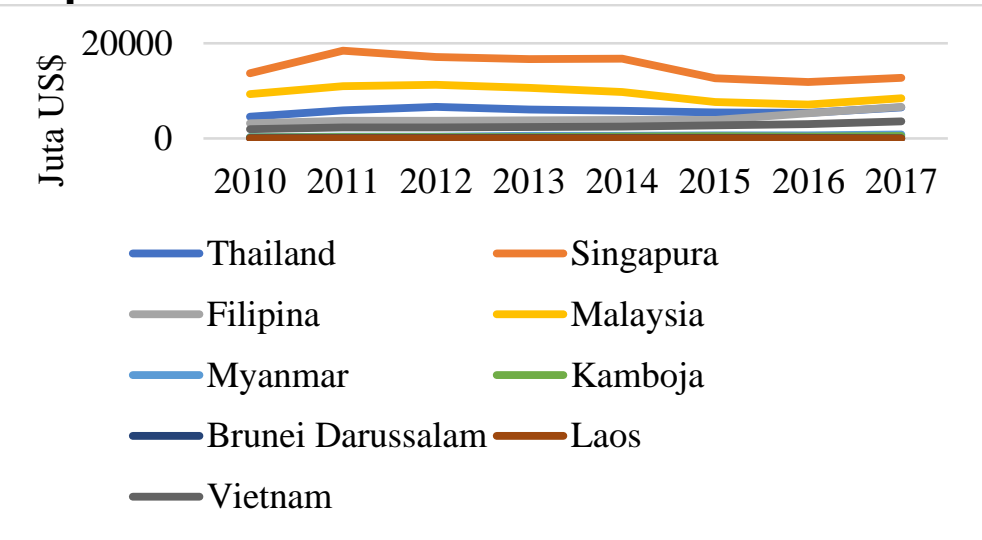

Sumber: BPS (diolah).

Gambar 3. Ekspor Indonesia ke negara anggota ASEAN tahun 2010-2017

Secara umum ekspor Indonesia ke negara-negara ASEAN cukup fluktuatif jika dilihat dari tahun 2010 hingga 2017. Berdasarkan Gambar 3 dapat dilihat bahwa pada tahun 2011 nilai ekspor Indonesia ke ASEAN meningkat dari US\$ 33,347 miliar pada tahun 2010 menjadi US\$ 42,098 miliar pada tahun 2011. Tahun 2011 ini nilai ekspor Indonesia ke ASEAN mengalami puncaknya selama periode 2010 hingga 2017. Kemudian nilai ekspor Indonesia ke ASEAN terus mengalami penurunan dari tahun 2012 hingga 2016. Pada tahun 2017 nilai ekspor Indonesia mulai naik lagi menjadi US\$ 39,266 miliar, walaupun nilai ini masih lebih rendah dibanding tahun 2011.

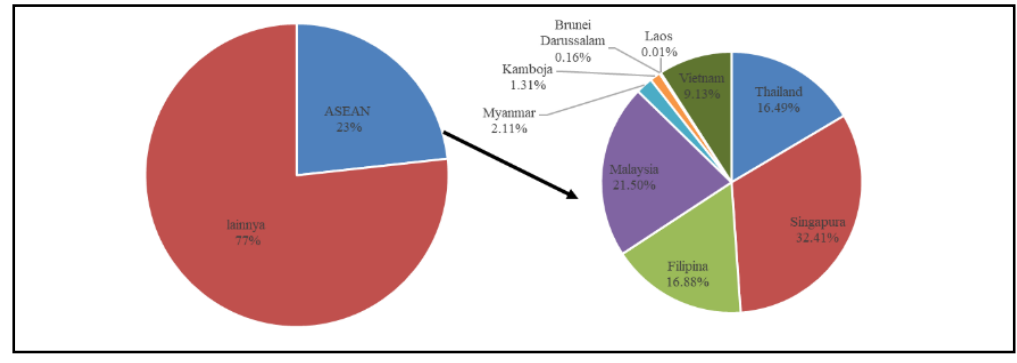

Sumber: BPS (diolah).

Gambar 4. Share Ekspor Indonesia ke negara anggota ASEAN tahun 2017

Berdasarkan Gambar 4 share ekspor Indonesia ke ASEAN pada tahun 2017 adalah sebesar 23 persen dari total ekspor Indonesia. Diantara negara-negara anggota ASEAN, Indonesia mengekspor paling banyak ke negara Singapura (32,41 persen). Kemudian diikuti Malaysia (21,50 persen), Filipina (16,88 persen), Thailand (16,49 persen) dan beberapa mitra dagang lainnya. 


\section{Gambaran Umum Impor Indonesia}

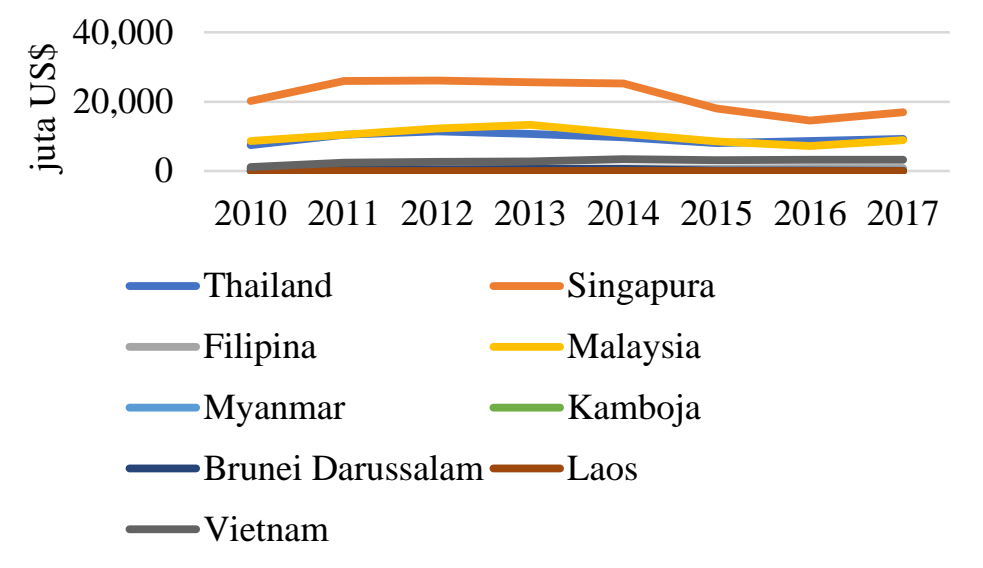

Sumber: BPS (diolah).

Gambar 5. Impor Indonesia dari negara anggota ASEAN tahun 2010-2017

Berdasarkan Gambar 5 dapat dilihat bahwa pada tahun 2011 nilai impor Indonesia dari ASEAN meningkat cukup signifikan dari US\$38,912 miliar pada tahun 2010 ke US\$ 51,108 miliar pada tahun 2011. Setelah itu, nilai impor Indonesia dari ASEAN terus meningkat hingga 2013. Pada tahun 2014 hingga 2016 nilai impor Indonesia mengalami penurunan, namun kembali meningkat pada tahun 2017.

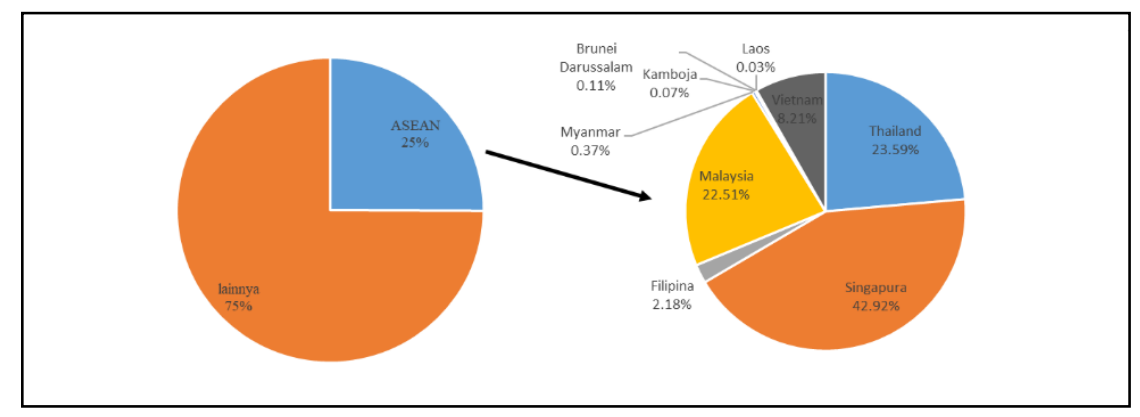

Sumber: BPS (diolah).

Gambar 6. Share Impor Indonesia dari negara anggota ASEAN tahun 2017

Berdasarkan Gambar 6 share impor Indonesia ke ASEAN pada tahun 2017 adalah sebesar 25 persen dari total impor Indonesia. Diantara negara-negara anggota ASEAN, Indonesia mengimpor paling banyak dari negara Singapura (42,92 persen). Kemudian diikuti Thailand (23,59 persen), Malaysia (22,51 persen), Vietnam (8,21 persen) dan beberapa mitra dagang lainnya.

\section{Analisis Faktor-faktor yang Memengaruhi Ekspor Indonesia ke Negara Anggota ASEAN Pemilihan Model Regresi Data Panel Terbaik}

Setelah uji Breush-Pagan Lagrange Multiplier dapat disimpulkan bahwa model terbaik untuk mengestimasi ekspor dan impor adalah model efek acak. Lalu dilakukan estimasi dengan semua variabel bebas, didapati bahwa variabel bebas yang signifikan mempengauhi nilai total ekspor Indonesia ke negara anggota ASEAN adalah PDB negara anggota ASEAN, indeks kesamaan, dan dan rasio industri terhadap PDB Indonesia. Sedangkan variabel bebas yang signifikan mempengauhi nilai total impor Indonesia dari negara anggota ASEAN adalah PDB Indonesia, jarak, indeks kesamaan, dummy MEA, dan rasio industri terhadap PDB negara anggota ASEAN.

\section{Pengujian Asumsi Klasik}

Pengujian asumsi normalitas dilakukan dengan melihat statistik Jarque Bera. Hasil ujinya menunjukkan bahwa nilai probabilitas Jarque Bera pada model ekspor dan impor lebih besar dari a sebesar 0,05 . Oleh sebab itu dapat ditarik kesimpulan bahwa asumsi normalitas pada kedua model telah terpenuhi. 
Asumsi yang selanjutnya diuji adalah asumsi nonmultikolinearitas. Uji nonmultikolinearitas ini dilakukan dengan melihat nilai Variance Inflation Factor (VIF). Asumsi non-multikolinieritas terpenuhi karena nilai VIF dari semua peubah bebas $\leq 10$.

Berikut adalah persamaan model ekspor yang terbentuk:

$$
\begin{aligned}
& \text { LnE } \widehat{\text { kspor }}_{i j t}=-31,9518+\hat{\lambda}_{i}+2,1189 \text { LnPDB }_{j t}-0,9516 \text { LnJarak }_{i j t}-0,7448
\end{aligned}
$$

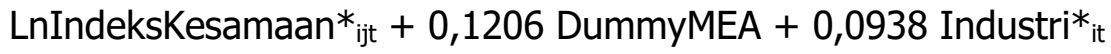

Dari hasil model ekspor yang terbaik didapati bahwa PDB negara anggota ASEAN signifikan berpengaruh secara positif terhadap ekspor Indonesia ke negara anggota ASEAN. Sehingga hal ini mengindikasikan bahwa dengan meningkatnya PDB negara importir akan menyebabkan kapasitas dari negara tersebut meningkat sehingga dapat meningkatkan impornya. Variabel rasio industri terhadap PDB juga signifikan berpengaruh secara positif terhadap ekspor Indonesia ke negara anggota ASEAN, ini menunjukkan bahwa ekspor akan meningkat seiring dengan semakin terindustrialisasinya suatu negara.

Sedangkan indeks kesamaan berpengaruh secara negatif terhadap ekspor Indonesia ke negara anggota ASEAN. Hal ini sejalan dengan penelitian yang dilakukan oleh Abu-Lila (2018) bahwa suatu negara akan cenderung melakukan perdagangan dengan negara dengan ukuran perekonomian yang berbeda dengannya, disebabkan oleh perbedaan kemajuan teknologi. Rasio dari nilai prediksi dan nilai yang sebenarnya akan digunakan untuk melihat potensi ekspor Indonesia ke negara anggota ASEAN, jika nilainya lebih besar dari satu maka perdagangan Indonesia dengan negara tersebut sangat direkomendasikan. Negara anggota ASEAN yang masih memiliki potensi besar untuk menjadi pasar ekspor Indonesia adalah Laos, Malaysia, Thailand, dan Brunei Darussalam. (Lampiran 3)

Jika dilihat dari nilai efek individunya pada Lampiran 4 maka dapat disimpulkan bahwa negara dengan nilai efek individu tertinggi adalah negara Kamboja, selanjutnya Vietnam dan Myanmar. Sehingga dapat dikatakan bahwa ketika semua variabel yang terdapat dalam penelitian tidak berpengaruh terhadap ekspor Indonesia ke negara anggota ASEAN maka ketiga negara tersebut memiliki nilai ekspor dari Indonesia yang paling besar. Sedangkan nilai efek individu yang terendah berturut-turut mulai dari negara Laos, Thailand dan Malaysia sehingga dapat dikatakan bahwa ketika semua variabel yang terdapat dalam penelitian tidak berpengaruh terhadap ekspor Indonesia ke negara anggota ASEAN maka ketiga negara tersebut memiliki nilai ekspor dari Indonesia yang paling kecil.

Berikut adalah persamaan model impor yang terbentuk:

$$
\begin{aligned}
& \text { LnImpor }_{i j t}=-52,5854+\hat{\gamma}_{i}+3,2816 \text { LnPDB }_{i t}-1,9825 \\
& \text { LnJarak }_{i j}+2,4850 \text { LnIndeksKesamaan } *_{i j t}-0,8187 \text { DummyMEA }^{*}+ \\
& 0,0734 \text { Industri }{ }_{\mathrm{jt}}
\end{aligned}
$$

Dari hasil model impor yang terbaik didapati bahwa PDB Indonesia secara signifikan berpengaruh positif terhadap impor Indonesia dari negara anggota ASEAN. PDB dari negara importir mengukur kapasitas absorbsi dari negara tersebut. Meningkatnya PDB dari negara importir menyebabkan kapasitas dari negara tersebut meningkat sehingga dapat meningkatkan impornya.

Lalu indeks kesamaan juga secara signifikan berpengaruh positif terhadap impor Indonesia dari negara anggota ASEAN. Hasil ini sejalan dengan teori Linder dimana negara yang memiliki kemiripan dalam ukuran perekonomiannya akan cenderung melakukan transaksi dagang terutama produk manufaktur. Rasio industri terhadap PDB negara anggota ASEAN secara signifikan berpengaruh 
positif terhadap impor Indonesia dari negara anggota ASEAN, sehingga dapat dikatakan bahwa ketika negara anggota ASEAN semakin meningkatkan sektor industrinya maka akan meningkatkan ekspor negaranya.

Variabel yang signifikan secara negatif berpengaruh terhadap impor Indonesia dari negara anggota ASEAN adalah jarak dan dummy MEA. Koefisien variabel dummy MEA yang negatif menandakan bahwa ketergantungan Indonesia terhadap impor dari negara anggota ASEAN sudah berkurang. Negara anggota ASEAN yang masih memiliki potensi untuk menjadi negara sumber impor Indonesia adalah Filipina, Malaysia, Laos, Myanmar dan Brunei Darussalam.(Lampiran 4).

Jika dilihat dari nilai efek individunya pada Lampiran 6 maka dapat disimpulkan bahwa negara dengan nilai individu tertinggi adalah negara Vietnam, selanjutnya Singapura dan Kamboja. Sehingga dapat dikatakan bahwa ketika semua variabel yang terdapat dalam penelitian tidak berpengaruh maka ketiga negara tersebut memiliki nilai impor oleh Indonesia yang paling besar.

\section{KESIMPULAN}

Ekspor dan impor Indonesia dengan negara anggota ASEAN cenderung mengalami penurunan dari tahun 2010-2017. Dimana negara Singapura, Malaysia, Thailand, dan Filipina mendominasi total perdagangan dengan Indonesia, dimana berdasarkan hasil model ekspor yang terbaik didapati bahwa PDB negara anggota ASEAN dan rasio industri terhadap PDB signifikan berpengaruh secara positif terhadap ekspor Indonesia ke negara anggota ASEAN, sedangkan indeks kesamaan berpengaruh secara negatif terhadap ekspor Indonesia ke negara anggota ASEAN. Variabel model gravitasi jarak didapati tidak signifikan berpengaruh terhadap ekspor Indonesia ke negara anggota ASEAN. Negara anggota ASEAN yang masih memiliki potensi besar untuk menjadi pasar ekspor Indonesia adalah Laos, Malaysia, Thailand, dan Brunei Darussalam. Sedangkan, dari hasil model impor yang terbaik didapati bahwa PDB Indonesia, indeks kesamaan, dan rasio industri terhadap PDB secara signifikan berpengaruh positif terhadap impor Indonesia dari negara anggota ASEAN, sebaliknya variabel yang signifikan secara negatif berpengaruh terhadap impor Indonesia dari negara anggota ASEAN adalah jarak dan dummy MEA. Model gravitasi tepat digunakan untuk melihat arus impor Indonesia dari negara anggota ASEAN. Impor Indonesia dari negara seperti Vietnam, Singapura, Kamboja dan Thailand sudah berlebihan.

\section{DAFTAR PUSTAKA}

Batra, A. (2004). India's Trade Potential: The Gravity Model Approach, Working Paper No. 151, Indian Council for Research on International Economic Relations.

Gujarati, D.N. \& Porter D.C. (2008). Basic Econometrics Fifth Edition. New York: Mc Graw Hill.

Kalbasi, H. (2001, July). The gravity model and global trade flows. In 75th International Conference on Policy Modeling for European and Global Issues, Brussels. July (pp. 5-7).

Lapipi. (2005). Analisis Efek Integrasi Ekonomi ASEAN dan Manfaatnya Bagi Perdagangan Negara-Negara ASEAN. Fakultas Ekonomi, Universitas Indonesia.

Linnemann, H. (1966). An Econometric Study of International Trade Flows. Amsterdam.

Helpman E, Krugman PR. (1985). Market Structure and Foreign Trade. MIT Press: Cambridge, MA.

Salvatore, D. (2007). International Economics. New Jersey: Prentice Hall. 
Timbergen, J. (1962). Shaping the World Economy: Suggestions for an International Economic Policy. New York: Twentieth Century Fund.

Greene, William H. (2012). Econometric Analysis: Seventh Edition. New Jersey: Prentice Hall.

Widyasanti, A. A. (2010). Do Regional Trade Areas Improve Export Competitiveness: A Case of Indonesia. Bulletin of Monetary, Economics and Banking, 13(1), 5-22.

Yeshineh, A. (2016). Determinants and Potentials of Foreign Trade in Ethiopia: A Gravity Model Analysis. Munich Personal RePEc Archive Paper No. 74509. 